\title{
Accessibility and Repayment of Agricultural Loan among Farmers in Benue State, Nigeria
}

\author{
Ezihe, J. A. C., Akpa, J. A. and Ayoola, J. B. \\ (Department of Agricultural Economics, Federal University of Agriculture, Makurdi, Benue State, Nigeria)
}

\begin{abstract}
The study determined the accessibility and repayment of agricultural loans among small-scale farmers in Benue State, Nigeria. Structured questionnaires were used to obtain information from 238 farmers randomly selected. Data were analysed with descriptive statistics, ordered logit regression and multiple regression analysis. Result shows that farmers have a mean age of 46.84 years and majority (77.3\%) of the farmers were males. Most (87.0\%) of the farmers were married and spent 9.9 years in acquiring formal education with experience of 22.4 years. Majority (82.4\%) of the respondents obtained informal loans. The age, sex, farm size and collateral value have a significant relationship on the level of farmer's access to formal loan. Similarly, sex, farm size, major occupation and interest rate were found to have a significant relationship on the level of access to informal loans. Farmer's loan repayment rate was $78.95 \%$ and $68.78 \%$ for formal and informal loans respectively. Marital status, major occupation, loan size, duration and number of instalments factors influencing the repayment of formal loan. However, loan size and number of instalments were the factors that have significant effect on repayment of informal loan. It was recommended that that conscious use of policies directed at increasing the amount of loan obtained by farmers should be promoted; disbursement of loan should be directed at farmers that have other sources of income.
\end{abstract}

Keywords: Collateral, Interest, Logit, Regression, Repayment

\section{Introduction}

Agricultural loan is a crucial input in smallholder agriculture. It enables farmers to establish and expand their farms as this would increase their income and ability to repay loans [1]. Agricultural credit is defined as the process of obtaining control over the use of money, goods and services in the present in exchange for a promise to repay at a future date. Credit is extended by lenders as loans [2].

Agricultural lending involves giving out of credit in (cash and in kind) to small-scale farmers for the purpose of farming. Financing agriculture is one of the most important factors to develop rural areas in developing countries [3]. Credit is an important instrument for improving the welfare of the poor directly through the consumption smoothening that reduces their vulnerability to short term income. It also enhances the production capacity of the poor resource farmers through financing investment in the human and physical capital [4].

The resolve by various stake holders in improving the status of the rural resource poor farmers through credit extension has informed a new policy dimension and question. The question of loan repayment by farmers is one of the important issues since it influences access to credit by the farmers [5]. In recent times, considerable interest has been shown by agricultural economists, planners, policy makers, agribusiness managers, agriculturists and financial institutions on the need to pay more attention to farmers in Nigeria. With this renewed interest in improving the status of the rural resource poor farmers through credit extension, a key issue that has cropped up is the question of loan repayment.

Agriculture is the bedrock of the Benue state economy. Majority of the farmers are poor, various approaches to empower them economically have been developed by the Nigerian government through many policies. Agricultural lending is a risky enterprise because repayment of loans can seldom be fully guaranteed (Kohansal and Mansoori, 2009).

Despite the importance of loan in agricultural production, its repayment is fraught with a number of problems especially in small holder farming. In Nigeria, farmers face a lot of problems in the acquisition, management and repayment of agricultural loans [6]. Institutionalized sources of credit are not willing to extend to small scale farmers which may be due to low level of loan repayment. This has adverse effect on agricultural development [7].

The broad objective of this study is the assessment of loan repayment among farmers in Benue state, Nigeria. Specifically, the study described the socio-economic characteristics of farmers in the study area; identify the sources of agricultural loan in the study area;estimated the determinant of level of access to agricultural loan in the study area;assess the repayment rate of farmersand examined the factors affecting loan repayment by farmers in the study. 


\section{1.The Study Area}

\section{Methodology}

The study area, Benue State lies in the Middle Belt of Nigeria between longitude $6^{0} 35^{\prime} \mathrm{E}$ to $10^{0} \mathrm{E}$ of the Greenwich Meridian and latitude $6^{0} 30^{\prime} \mathrm{N}$ to $8^{0} 10^{\prime} \mathrm{N}$ of the equator. The State shares boundaries with six states namely, Nassarawa to the North, Taraba to the East, Cross-River to the South, Kogi to the West and Enugu/Ebonyi to the South West as well as Republic of Cameroon to the South East. The State has a population of 4,219,244 [8]. Benue State experiences a typical tropical climate with two distinct seasons, the wet or rainy season and the dry season. The rainy season lasts from April to October with annual rainfall in the range of 150 $-180 \mathrm{~mm}$. The dry season begins in November and ends in March. Most of the people in the State are farmers while inhabitants of the riverine areas engage in fishing as their primary or important secondary occupations. Benue State is acclaimed the nation's food basket because of its diverse rich agricultural produce which includes yams, rice, beans, cassava, soybeans, benniseed, maize, sorghum, millet, tomatoes and a lot of fruits. Poultry, goat, sheep, pigs and cattle are the major domestic animals kept.

\subsection{Population and Sampling procedure}

Multi-stage sampling technique was used to select the respondents. The first stage was a purposive sampling of two Local Government areas each from the three agricultural zones given a total of six local government areas because of their deep involvement in agricultural production. Secondly, three farming communities were randomly selected from each of the local government selected. Thirdly, fourteen farmers were further selected randomly from each of the communities, giving a total number of 252 farmers, although only 238 questionnaires retrieved were valid for this study.

\subsection{Data Collection Technique}

Data for this study were collected from primary sources using structured questionnaires and were analized using descriptive statistics, multiple and ordered logistic regression.

\subsection{Model Specification}

\subsection{Ordered logistic Regression Model}

This is a regression model for ordinal dependent variables. It is an extension of the logistic regression model that applies dichotomous dependent variables allowing for more than two response categories. The model only applied to data that meet the odds assumption that the relationship between any two pairs of outcome groups is statistically the same. This means that the coefficient that describes the relationship between say, the lowest versus all higher categories of the response variables are the same as those that describe between the next lowest category and all higher categories, etc. because the relationship between all pairs of a group is the same; there is only one pair of coefficient. The model is usually estimated using maximum likelihood. Ordered logit model is appropriate when analyzing data with dependent variables that has more than two ordered response level.

In order to estimate the determinants of access to loan, ordered logit regression was employed. The response variable which is the level of access to loan for this study is defined by three ordered categories: high access, moderate access or low access to formal and informal loan coded as 1, 2, 3 respectively.

The model is specified thus:

$\operatorname{Pr}(Y \leq j)=$

$\ln \left(\frac{P(Y \leq j / X}{P(Y>j / X}\right)$

It then means that:

$\operatorname{Pr}(Y \leq j)=\ln \left(\frac{\sum \mathrm{p}(\mathrm{Y} \leq \mathrm{j} / \mathrm{X})}{1-\sum \mathrm{P}(\mathrm{Y} \leq \mathrm{j} / \mathrm{X}}\right)=\propto_{j}+\beta_{1} X_{1}+\cdots+$

$\beta 13 \times 13$......

$\mathrm{j}=1,2,3, \ldots, 13$

Where:

$\mathrm{Y}=$ access to loan categorized into 3: low access $=1$; moderate access $=2$ and high access $=3$

$\propto=$ threshold

$\beta_{1}-\beta_{9}=$ logistic coeficients for the independent variables

$\operatorname{LnPr}\left(\mathrm{Y}_{\mathrm{j}}=\mathrm{i}\right)=\ln \propto+\beta_{1} \ln \mathrm{X}_{1}+\beta_{2} \ln \mathrm{X}_{2}+\beta_{3} \ln \mathrm{X}_{3}+\beta_{4} \ln \mathrm{X}_{4}+\beta_{5} \ln \mathrm{X}_{5}+\beta_{6} \ln \mathrm{X}_{6}+\beta_{7} \ln \mathrm{X}_{7}+\beta_{8} \ln \mathrm{X}_{8}+$

$\beta_{9} \ln X_{9}+\beta_{10} \ln X_{10}+\beta_{11} \ln X_{11}+\beta_{12} \ln X_{12}+\beta_{13} \ln X_{13}+$

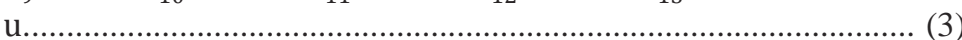

$\mathrm{X}_{i}=$ independent variables; $\mathrm{X}_{1}=\mathrm{Sex}$ (Dummy; Male $=1$, Female $\left.=0\right) ; \mathrm{X}_{2}=$ Age $($ Years $) ; \mathrm{X}_{3}=$ Marital Status (Dummy: Married $=1$, Single $=0) ; \mathrm{X}_{4}=$ Household size (Number); $\mathrm{X}_{5}=$ Experience $\left(\right.$ years) $; \mathrm{X}_{6}=$ Farm size 
(hectares); $\mathrm{X}_{7}=$ Farm Income (Naira) $; \mathrm{X}_{8}=$ off-farm Income (Naira); $\mathrm{X}_{9}=$ Occupation; $\mathrm{X}_{10}=$ Distance from credit source (Kilometers); $\mathrm{X}_{11}=$ Interest rate (Percentage); $\mathrm{X}_{12}=$ Education; $\mathrm{X}_{13}=$ Collateral value

\subsubsection{Multiple Regression model}

The estimated model for determinants of loan repayment is explicitly stated below:

$\mathrm{Y}=\mathrm{F}\left(\mathrm{X}_{1}, \quad \mathrm{X}_{2}, \quad \mathrm{X}_{3}, \quad \mathrm{X}_{4}, \quad \mathrm{X}_{5} \quad \mathrm{X}_{6}, \quad \mathrm{X}_{7}, \quad \mathrm{X}_{8}, \mathrm{X}_{9}, \mathrm{X}_{10}, \mathrm{X}_{11}, \quad \mathrm{X}_{12}, \quad \mathrm{X}_{13,}\right.$

Where: $Y=$ Amount of loan repaid; $X_{1}=A g e$ (naira); $X_{2}=\operatorname{Sex}($ male $=1$, Female $=0) ; X_{3}=$ Marital status (married $=1$; others $=0$ ); $\mathrm{X}_{4}=$ Family size (number); $\mathrm{X}_{5}=$ Level of education (number of years spent in formal educational institution; $\mathrm{X}_{6}=$ Farm size (hectare); $\mathrm{X}_{7}=$ Annual farm income (naira); $\mathrm{X}_{8}=$ Off-farm income (naira); $\mathrm{X}_{9}=$ Occupation(Farming $=1$; others $\left.=0\right) ; \mathrm{X}_{10}=$ Interest rate $(\%) ; \mathrm{X}_{11}=$ Loan size (naira); $\mathrm{X}_{12}=$ Duration (years); $\mathrm{X}_{13}=$ Instalments (Number) and $\mathrm{U}=$ error term.

The model specified was subjected to three functional forms and the lead equation was selected based on the econometric and statistical criteria. The estimated functions will be evaluated in terms of the magnitude of the coefficients of multiple determinants $\left(\mathrm{R}^{2}\right)$, the significance of the coefficients and the magnitude of the standard errors. The three functional forms to be fitted are linear, semi log, Cobb-Douglas forms.

\section{Linear Form}

$Y=b_{0}+b_{1} X_{1}+b_{2} X_{2}+b 3 X_{3}+b_{4} X_{4}+b_{5} X_{5}+b_{6} X_{6}+b_{7} X_{7}+b_{8} X_{8}+b_{9} X_{9}+b_{10} X_{10}+b_{11} X_{11}+b_{12} X_{812}+b_{13} X_{13}+$ $\mathrm{U}$.

\section{Semi - logarithmic Form}

$\mathrm{Y}=\mathrm{Lnb}_{0}+\mathrm{b}_{1} \operatorname{LnX}_{1}+\mathrm{b}_{2} \operatorname{LnX}_{2}+\mathrm{b}_{3} \operatorname{LnX}_{3}+\mathrm{b}_{4} \operatorname{LnX} X_{4}+\mathrm{b}_{5} \operatorname{LnX}_{5}+\mathrm{b}_{6} \operatorname{LnX}_{6}+\mathrm{b}_{7} \operatorname{LnX} X_{7}+\mathrm{b}_{8} \operatorname{LnX}_{8}+\mathrm{b}_{9} \operatorname{LnX}_{9}+\mathrm{b}_{10} \operatorname{LnX}_{10}+$ $\mathrm{b}_{11} \operatorname{LnX}_{11}+\mathrm{b}_{12} \mathrm{LnX}_{12}+\mathrm{b}_{13} \operatorname{LnX} \mathrm{X}_{13}+$ U.

Double - logarithmic Form

$\mathrm{LnY}=\mathrm{Lnb}_{0}+\mathrm{b}_{1} \operatorname{LnX}_{1}+\mathrm{b}_{2} \operatorname{LnX}_{2}+\mathrm{b}_{3} \operatorname{LnX}_{3}+\mathrm{b}_{4} \operatorname{LnX} \mathrm{X}_{4}+\mathrm{b}_{5} \operatorname{LnX}_{5}+\mathrm{b}_{6} \operatorname{LnX}_{6}+\mathrm{b}_{7} \operatorname{LnX}_{7}+\mathrm{b}_{8} \operatorname{LnX}_{8}+\mathrm{b}_{9} \operatorname{LnX}_{9}+\mathrm{b}_{10} \operatorname{LnX}_{10}$ $\begin{array}{llllll}\mathrm{b}_{11} \operatorname{LnX}_{11} & + & \mathrm{b}_{12} \operatorname{LnX}_{12} & + & \mathrm{b}_{13} \operatorname{LnX}_{13}\end{array}$ $\mathrm{U}$

Where $\mathrm{Ln}=$ natural logarithms

$\mathrm{b}_{0}, \mathrm{~b}_{1} \ldots \mathrm{b}_{13}=$ estimated coefficients

\section{1.Socio-economic Characteristics of Respondents}

\section{Results And Discussion}

The age distribution of the farmers indicates that farmers have a mean age of 46.84 years. This implies that the farmers in the study area are still in their active and productive stage. The distribution of the respondents according to sex shows that $77.3 \%$ of the respondents were males while $22.7 \%$ of them were females. The males have the natural strength to embark on farming which is characterised by drudgery.

In terms of education, result shows that majority (42.0\%) of the farmers spent 7-12 years in formal education. On the average, years spent in acquiring formal education by the respondents is 9.9 years. This implies that the farmers are literate. On farming experience, analysis reveals that majority (33.6\%) of the farmers have between 11-20 years of experience. The result also shows a mean of 22.4 years. This implies that farmers have long years of experience which may be of some importance to their accessibility and repayment of loan. The mean of the farming income of respondents was $\$ 224953.98$. This implies that the farmers generate much income from farming. This will boost their confidence in farming venture thereby increase the likelihood to obtain loan.

Table 1: Distribution of the Socio- Economic characteristics of Respondents

\begin{tabular}{|l|l|l|l|}
\hline Variables & Frequency & Percentage & Mean \\
\hline Sex & & & \\
\hline Female & 54 & 22.7 & \\
\hline Male & 184 & 77.3 & \\
\hline Age & & & 46.82 \\
\hline 20 and below & 1 & 0.4 & \\
\hline $21-40$ & 81 & 34.0 & \\
\hline $41-60$ & 128 & 53.8 & \\
\hline 61 and above & 28 & 11.8 & \\
\hline Marital status & & & \\
\hline Married & 207 & 87.0 & \\
\hline Others & 31 & 13.0 & \\
\hline Family size & & & 8.72 \\
\hline
\end{tabular}




\begin{tabular}{|c|c|c|c|}
\hline 5 and below & 67 & 28.1 & \\
\hline $6-10$ & 112 & 47.1 & \\
\hline $11-15$ & 44 & 18.5 & \\
\hline 16 and above & 15 & 6.3 & \\
\hline Years of formal education & & & 9.90 \\
\hline Below 1 & 34 & 14.3 & \\
\hline $1-6$ & 30 & 12.6 & \\
\hline $7-12$ & 100 & 42.0 & \\
\hline 13 and above & 74 & 31.1 & \\
\hline Farming experience & & & 22.04 \\
\hline 10 and below & 47 & 19.7 & \\
\hline $11-20$ & 80 & 33.6 & \\
\hline $21-30$ & & 26.5 & \\
\hline Farm size & & & 3.71 \\
\hline 1 and below & 43 & 18.1 & \\
\hline $1.01-2.00$ & 62 & 26.0 & \\
\hline $2.01-3.00$ & 28 & 11.8 & \\
\hline 3.01 and above & 105 & 44.1 & \\
\hline Farm income & & & 224953.78 \\
\hline 100000 and below & 92 & 38.6 & \\
\hline $100001-200000$ & 84 & 35.3 & \\
\hline $200001-300000$ & 34 & 14.3 & \\
\hline 300000 and above & 28 & 11.8 & \\
\hline Off-farm income & & & 195411.77 \\
\hline 100000 and below & 153 & 64.3 & \\
\hline $100001-200000$ & 48 & 20.2 & \\
\hline $200001-300000$ & 16 & 6.70 & \\
\hline 300000 and above & 21 & 8.8 & \\
\hline \multicolumn{4}{|l|}{ Major occupation } \\
\hline Farming & 174 & 72.1 & \\
\hline Others & 64 & 26.9 & \\
\hline
\end{tabular}

Source: Field survey, 2016

\subsection{Distribution of the Sources of Loan of Respondents}

The result of the analysis of the sources of agricultural loan of respondents as contained in table 2 shows that majority (82.4\%) of the respondents obtained informal agricultural loans while17.6\% obtained loans from formal sources. This conforms to the report of [ 9 who found that only $16.67 \%$ of cassava farmers in ObotAkara Local Government Area of Akwa Ibom state sourced loans from formal institutions. The formal sources of credit available to farmers are commercial banks, Bank of Agriculture and micro finance bank. Among these, micro finance bank shows a greater $(7.1 \%)$ percentage while co-operative represents a greater $(31.6 \%)$ source of informal loan.

Table 2: Respondents' Sources of Agricultural Loan

\begin{tabular}{|l|l|l|}
\hline Source & Frequency & Percentage \\
\hline Commercial Bank & 13 & 5.5 \\
\hline Bank of Agriculture & 12 & 5.0 \\
\hline Micro finance Bank & 17 & 7.1 \\
\hline Sub-total & 42 & 17.6 \\
\hline Money lenders & 30 & 12.6 \\
\hline Friends and Family & 42 & 17.6 \\
\hline Cooperative & 75 & 31.6 \\
\hline Rotatory savings & 49 & 20.6 \\
\hline Sub-total & 169 & 82.4 \\
\hline Grand total & 238 & 100 \\
\hline
\end{tabular}

Source: Field survey, 2016

\subsection{Determinant of the Level of Farmer's Access to Loan}

The estimation of the determinants of the farmers access to formal and informal loans in the study area were separately analysed using STATA 12 software. The response variable which was level of access to formal and informal loans was defined by three ordered categories: low access, moderate access and high access, coded as 1, 2 and 3 respectively. The result of the parameter estimates (estimated coefficients along with $\mathrm{Z}$ values and the marginal effects after logit) is presented in table 5. The Likelihood ratio (LR) chi square for both formal and informal loan models was significantly different from zero at $1 \%$ levels. This implies that the socio economic and other factors included in the models are significantly related to the levels of access to formal and informal loans. From the ordered logistic regression, determinants of level of access were identified. The study used the parameter estimated and the marginal effect after logit to interpret the behaviour of the determinants of the level of access to formal and informal agricultural loans. Evidence from the models as contained in table 5 showed that the set of explanatory variables varied across the categories in terms of the levels of significance and signs. 
The positive signs suggested that an increase in the variable is associated with a higher category (in this case, high access to (3)), while a negative and significant parameter meant that an increase in the variable is associated with lower category (in this case, low access (1)).

Age has a significant positive effect on access to formal loan at $10 \%$ level. This shows a marginal effect of 0.0090716 . This means that the higher the age of farmers, the higher their access to formal loan. This also implies that an increase in the age of the farmers will result in $0.009 \%$ increase in high access to formal loan. This result opposes the finding of Asogwa et al.[10] who found a negative relationship between age and access to loan among peasant farmers in Benue State, Nigeria.

Sex had an inverse and significant relationship with the level of access to formal loan at $5 \%$ level of significance with the marginal effect of 0.6461261 . This implies that a unit increase in the in farmers will lead in $0.6461261 \%$ increase in low access to formal loan which means that the males have low access to formal loan than the females. This is contrary to the findings of Ololade and Olagunju [11] who suggested that the males have better access to loan in Oyo state, Nigeria.

However, sex (0.6686119) is found to have a positive relationship with farmer's access to informal loans. This also shows a marginal effect of 0.0214002. This means that the males had $0.0214002 \%$ higher access to informal loans than their female counterparts. This is found to be significant at $10 \%$. This supports the result of Awunyo-Victor (2010) who found a positive relationship between sex and participation in informal loan significant at $5 \%$ in Ghana.

Farm size shows a direct relationship with access to formal loan at $5 \%$ level with a marginal effect of 0.0090716. This implies that an increase in the size of farm land increases high access to formal loan by $0.0090716 \%$. This result agrees with the findings of Asogwa et al [10] who found a direct significant relationship between farm size and access to loan.

Farm size (-0.2280665) is found to have a negative influence on level of farmer's access to informal loan at $1 \%$ level with a marginal effect of 0.049344 . This means that a unit increase in the size of farm land results in $0.049344 \%$ farmer's low access to informal loan. This opposes the findings of Etohinu, Rahman and Usman [12] who found a positive relationship between loan access rate and farm size in Nassarawa state, Nigeria although not significant.

Collateral value $\left(80.03 \mathrm{e}^{-07}\right)$ had a positive and significant relationship with access to formal loan at $5 \%$ level. The variable has a marginal effect of $1.50 \mathrm{e}-08$. This means that for a $\$ 1$ increase in the value of collateral, the farmer's high access to formal loan increases by $1.51 \mathrm{e}-08 \%$. This suggests that farmer's access to formal loan becomes better as the value of the collateral increases. This opposes the findings of Ololade and Olagunju [11 who found a negative relationship between collateral value and farmer's access to loan although this was not significant.

Major occupation (-0.8270239) is found to have a negative relationship with the level of access to informal loan with a marginal effect of 0.1790419 at $5 \%$ level of significance. This means that respondents who have farming as their major occupation have $0.1790419 \%$ low access to informal loan. This agrees with the result of Ololade and Olagunju [11] who also found a negative relationship between occupation and access to loan in Oyo state, Nigeria.

Interest $(0.0548050)$ is found to have a positive relationship with access to informal loan with a marginal effect of 0.0020184 . It means that a $1 \%$ increase in the interest rate results in $0.0020184 \%$ increase in high access to informal loan. This agrees with the study of Ololade and Olagunju [11] who found a significant positive relationship between farmer's access to loan and interest loan charged in Oyo state, Nigeria.

Table 3: Parameter Estimates of the Ordered Logit Regression for factors affecting Loan Repayment

\begin{tabular}{|c|c|c|c|c|c|c|}
\hline Variables & Coefficient & $\mathrm{Z}$ & $\mathrm{P}>/ \mathrm{z} /$ & 1 & 2 & 3 \\
\hline \multicolumn{7}{|l|}{ Formal } \\
\hline ex & -3.084651 & $-2.10^{6 m}$ & 0.036 & 06461261 & -0.4308106 & -0.2153155 \\
\hline Age & 0.121981 & $1.02^{* * *}$ & 0.085 & -0.205221 & 0.0182243 & 0.0022978 \\
\hline Marital status & -2.106387 & -1.30 & 0,193 & 0.4604111 & -0.3641169 & -0.0962942 \\
\hline Household size & 0.0281958 & 0.24 & 0.813 & -0.0047437 & 0.0042125 & 0.0005311 \\
\hline Experience & -0.867763 & -1.52 & 0.129 & 0.0145993 & -0.0129646 & -0.0016347 \\
\hline Farm size & 0.4815655 & $2.09^{* *}$ & 0.036 & -0.0810188 & 0.0719472 & 0.0090716 \\
\hline Farm income & $-4-52 e-07$ & -0.45 & 0.651 & $7.60 \mathrm{e}-08$ & $-6.75 e-08$ & $-8.51 \mathrm{e}-08$ \\
\hline Off farm income & $7.38-07$ & 0.36 & 0.720 & $-1.24 \mathrm{e}-07$ & $1.10 \mathrm{e}-07$ & $1.39 \mathrm{e}-08$ \\
\hline Occupation & -0.3691718 & -0.330 & 0.743 & 0.0624163 & -0.0553676 & -0.0070487 \\
\hline Distance & -0.0215278 & -0.47 & 0.637 & 0.0036218 & -0.0032163 & -0.004055 \\
\hline Interest rate & 0.0248984 & 0.36 & 0.716 & -0.0041876 & 0.0037188 & 0.0004689 \\
\hline Education & 0.1140759 & 0.96 & 0.338 & -0.0191922 & 0.0170433 & 0.0021489 \\
\hline Collateral value & $8.03 e-07$ & $2.30^{\text {काल }}$ & 0.021 & $-1.35 \mathrm{e}-07$ & $1.20 \mathrm{e}-07$ & $1.51 \mathrm{e}-08$ \\
\hline $\mathrm{N}$ & 42 & & & & & \\
\hline LR Chi2 & 29,68 & & & & & \\
\hline Prob>Chi2 & 0.0052 & & & & & \\
\hline Pseudo R2 & 0.4019 & & & & & \\
\hline
\end{tabular}




\begin{tabular}{|c|c|c|c|c|c|c|}
\hline Cut 1 & 4.640231 & & & & & \\
\hline Cut 2 & 7.272738 & & & & & \\
\hline \multicolumn{7}{|l|}{ Informal } \\
\hline Sex & 0.6686119 & $1.65^{* * *}$ & 0.100 & -0.1348078 & 0.1134075 & 0.0214002 \\
\hline Age & -0.0154301 & -0.72 & 0.474 & 0.0033405 & -0.0027722 & -0.005683 \\
\hline Marital status & -0.0943172 & -0.19 & 0.848 & 0.0206715 & -0.070842 & -0.0035874 \\
\hline Household size & 0.0450574 & 1.11 & 0.267 & -0.0097545 & 0.0080951 & 0.0016594 \\
\hline Experience & 0.0183379 & 0.88 & 0.377 & -0.00397 & 0.0032946 & 0.0006754 \\
\hline Farm size & -0.2280665 & $-3.57^{*}$ & 0.010 & 0.049374 & -0.040946 & -0.0083994 \\
\hline Farm income & $1.04 \mathrm{e}-07$ & 0.12 & 0.906 & $-2.24 \mathrm{e}-0.8$ & $1.86 \mathrm{e}-08$ & $3.82 \mathrm{e}-09$ \\
\hline Off farm income & $-3.73 e-07$ & -0.38 & 0.707 & $-8.08 \mathrm{e}-08$ & $-6.71 e-08$ & $-1.37 \mathrm{e}-08$ \\
\hline Occupation & -0.8270239 & $-2.00^{*+1}$ & 0.046 & 0.1790419 & -0.1485838 & -0.304581 \\
\hline Distance & 0.0197062 & 0.91 & 0.363 & -0.0042662 & 0.0035404 & 0.0007258 \\
\hline Interest rate & 0.0548053 & $2.65^{*}$ & 0.008 & -0.118648 & 0.0098464 & 0.0020184 \\
\hline Education & -0.0346964 & -1.01 & 0.311 & 0.0075114 & -0.0062336 & -0.0012778 \\
\hline $\mathrm{N}$ & 196 & & & & & \\
\hline $\operatorname{LR~Chi}^{2}(12)$ & 31.52 & & & & & \\
\hline Prob $>$ Chi 2 & 0.0016 & & & & & \\
\hline Pseudo R2 & 0.1001 & & & & & \\
\hline Cut 1 & -0.2619324 & & & & & \\
\hline Cut 2 & 2.193587 & & & & & \\
\hline
\end{tabular}

Note: $*$, ** denotes $\mathrm{z}$-test significant at 1\%,5\% and 10\% levels respectively. 1, 2 and 3 represents marginal effects for low access, moderate access and high access respectively.

Source: Field Survey, 2016

\subsection{Amount of Loan Received and Repaid by Farmers}

Table 4 represents the distribution of the amount of loan obtained and repaid by farmers. It shows that the mean amount of loan obtained from formal sources is 25297619 with a high standard deviation of 380283.370. The average amount of formal loan repaid by respondents stood at 199726.19. This represents a repayment rate of $78.95 \%$ similar to the repayment rate of $78.02 \%$ found by Olagunju and Adeyemo [13] in Western Nigeria. Table 4 also shows that the mean amount of loan obtained from informal sources was N52006.33 which is similar to the $\$ 50536.7$ reported by Oboh and Kushwaha (2009) in Benue State. The mean amount repaid is $\mathrm{N} 35808.72$. This results in a repayment rate of $68.78 \%$. This figure is lower than the $71.1 \%$ rate found by Ojiako and Ogbukwa [15] among cooperative farmers in Ogun State, Nigeria.

Table 4: Distribution of the Amount of Loan Received and Repaid by Farmers

\begin{tabular}{|l|l|l|l|l|l|}
\hline & Minimum & Maximum & Mean & Standard deviation & Repayment rate \\
\hline Formal & & & & & \\
\hline Amount received & 0 & 2000000 & 252976.19 & 377027.947 & \\
\hline Amount repaid & 0 & 4000000 & 199726.19 & 380283.370 & $78.95 \%$ \\
\hline Informal & & & & & \\
\hline Amount received & 0 & 600000 & 52066.33 & 84378.213 & \\
\hline Amount repaid & 0 & 350000 & 35808.72 & 61960.893 & $68.78 \%$ \\
\hline
\end{tabular}

Source: Field survey, 2016

\section{5.Factors Influencing Formal and Informal Loan Repayment}

The ordinary least squares (OLS) regression analysis was carried out to determine factors which influence farmer's loan repayment. The data were fitted to three functional forms: linear, semi-logarithms and double logarithms functions. The result of the estimations of loan repayment is presented in table 5. For the factors influencing formal loan repayment, the linear functional form was found to be the lead equation of the regression for the formal loan repayment model because it has the highest $\mathrm{R}^{2}$. The regression result shows significant the coefficient of determination $\left(\mathrm{R}^{2}\right)$ was 0.984 which means that the variables were able to explain about $98 \%$ of the total variables for the determination of formal loan repayment. The F-ratio was 120.647 and significant at $1 \%$ implying that the joint effect of all the included variables were significant.

For the factors influencing repayment of informal loans, among the three functional forms that were tried, the double logarithm function was chosen. This has highest $\mathrm{R}^{2}$ of 0.915 which means that the variables included in the equation can explain $91.5 \%$ of the total variables of factors influencing the repayment of informal loans. It also has the least magnitude of standard error (2.3456) and two of the variables are found to be significant from the fourteen variables included. These are loan size and number of instalment.

The coefficient of size of loan obtained $\left(\mathrm{X}_{12}\right)$ was found to be positively and significantly related to formal loan repayment at $1 \%$ level. This suggests that the amount of loan disbursed to farmers has a direct relationship with the amount repaid. This implies that an increase in the amount of loan obtained will lead to an increase in the amount repaid by farmers. This supports the findings of Ajah et al. [17] who found a positive coefficient of loan size relating to repayment among poultry farmers in Cross River state, Nigeria. Loan size is also found to have positive relationship significant (10\%) with the repayment of informal loan. This confirms 
the findings of Ojiako and Ogbukwa [15] who also found a positive significant relationship between informal loan repayment and loan size among cooperative farmers in Yewa Local Government Area of Ogun State, Nigeria.

Major occupation $\left(\mathrm{X}_{10}\right)$ was found to have a negative sign and significant at 5\% level on the formal loan repayment model. This means that respondents who have major occupations other than farming will repay higher amount of loan than their counterparts. This finding is similar to the result of Akpan et al.[18] who found a direct relationship between occupation and loan repayment default among beneficiaries of Agricultural Credit Guarantee Scheme in Akwa Ibom, Nigeria.

The result also shows that the marital status $\left(\mathrm{X}_{3}\right)$ of respondents is significantly related to the amount of formal loan repaid at 5\% level. It bears a negative sign signifying an inverse relationship. This means that farmers who are not married are more likely to repay loans. This agrees with the study of Wognaa and AwunyoVictor [19] who found a negative relationship between marital status and loan repayment performance in the Sene district, Ghana.

Loan duration (-6073.701) had an inverse and significant effect on formal loan repayment at $1 \%$ level. This means that the longer the duration of the loan, the less amount farmers will repay. This agrees with the findings of Akpan et al.[18] who found a direct relationship between loan duration and loan repayment default among beneficiaries of Agricultural Credit Guarantee Scheme in Akwa Ibom, Nigeria.

Furthermore, the result reveals that the number of instalment of loan $\left(\mathrm{X}_{14}{ }^{\prime}\right.$ is directly related to the amount of formal and informal loan repaid. This is found to be significant at $1 \%$ level. This suggests that the higher the number of instalment agreed, the higher the amount of loan repaid. This opposes the study of Kohansal and Mansoori [3] who found a negative influence on the number of instalment and loan repayment performance among farmers in Khorasan-Razavi province of Iran.

Table 5: Parameter Coefficients for Factors Affecting Farmer's Loan Repayment

\begin{tabular}{|c|c|c|c|c|c|c|}
\hline Variables & Linear & $\begin{array}{l}\text { Formal } \\
\text { Semi-log }\end{array}$ & Double-log & Linear & $\begin{array}{l}\text { Informal } \\
\text { Semi-log }\end{array}$ & Double-log \\
\hline Constant & $\begin{array}{l}59070.127 \\
(0.902)\end{array}$ & $\begin{array}{l}-1856614,751 \\
(-1.908)\end{array}$ & $\begin{array}{l}5.914 \\
(0.555) \\
\end{array}$ & $\begin{array}{l}-11155.875 \\
(-0.672) \\
\end{array}$ & $\begin{array}{l}-208067.938 \\
(-2.886) \\
\end{array}$ & $\begin{array}{l}-1.978 \\
(-0.552) \\
\end{array}$ \\
\hline Age & $\begin{array}{l}445.809 \\
(0.339) \\
\end{array}$ & $\begin{array}{l}-73974.600 \\
(-0.234)\end{array}$ & $\begin{array}{l}-3.601 \\
(-1.020) \\
\end{array}$ & $\begin{array}{l}414.228 \\
(1.328)\end{array}$ & $\begin{array}{l}45083.079 \\
(2.348) * * *\end{array}$ & $\begin{array}{l}0.032 \\
(0.033)\end{array}$ \\
\hline Sex & $\begin{array}{l}55747.736 \\
(9.746) \\
\end{array}$ & $\begin{array}{l}-6378.984 \\
(-0.041) \\
\end{array}$ & $\begin{array}{l}1.070 \\
(0.625) \\
\end{array}$ & $\begin{array}{l}6251.747 \\
(1.087) \\
\end{array}$ & $\begin{array}{l}7078.731 \\
(0.872) \\
\end{array}$ & $\begin{array}{l}-0.290 \\
(-0.719) \\
\end{array}$ \\
\hline Marital status & $\begin{array}{l}-11279.579 \\
(-2.571) * * \\
\end{array}$ & $\begin{array}{l}-617286.802 \\
(-3.422) * \\
\end{array}$ & $\begin{array}{l}-1.386 \\
(-0.702) \\
\end{array}$ & $\begin{array}{l}-923.811 \\
(-0.118) \\
\end{array}$ & $\begin{array}{l}-11967.331 \\
(-1.073) \\
\end{array}$ & $\begin{array}{l}0.068 \\
(0.123) \\
\end{array}$ \\
\hline Family size & $\begin{array}{l}-597.131 \\
(-0.335) \\
\end{array}$ & $\begin{array}{l}-29366.427 \\
(-0.239)\end{array}$ & $\begin{array}{l}-1.941 \\
(1.445) \\
\end{array}$ & $\begin{array}{l}-465.533 \\
(-0.744)\end{array}$ & $\begin{array}{l}3004.097 \\
(0.357)\end{array}$ & $\begin{array}{l}0.629 \\
(1.505)\end{array}$ \\
\hline Education & $\begin{array}{l}1675.080 \\
(0.599) \\
\end{array}$ & $\begin{array}{l}21773.173 \\
(0.644) \\
\end{array}$ & $\begin{array}{l}0.240 \\
(0.649) \\
\end{array}$ & $\begin{array}{l}354.161 \\
(0-658) \\
\end{array}$ & $\begin{array}{l}1664.138 \\
(1.080) \\
\end{array}$ & $\begin{array}{l}-0.029 \\
(-0.381) \\
\end{array}$ \\
\hline Experience & $\begin{array}{l}1058.807 \\
(0.923)\end{array}$ & $\begin{array}{l}61080.250 \\
(-0.668)\end{array}$ & $\begin{array}{l}0.787 \\
(0.786) \\
\end{array}$ & $\begin{array}{l}-308.981 \\
(-0.961) \\
\end{array}$ & $\begin{array}{l}1663.179 \\
(0.235) \\
\end{array}$ & $\begin{array}{l}0.289 \\
(0.799) \\
\end{array}$ \\
\hline Farm size & $\begin{array}{l}-1706.564 \\
(-0.334) \\
\end{array}$ & $\begin{array}{l}-3879.422 \\
(-0.496) \\
\end{array}$ & $\begin{array}{l}-0.649 \\
(0.758) \\
\end{array}$ & $\begin{array}{l}-123.854 \\
(-0.961) \\
\end{array}$ & $\begin{array}{l}4407.842 \\
(0.785) \\
\end{array}$ & $\begin{array}{l}0.281 \\
(0.132) \\
\end{array}$ \\
\hline Farm income & $\begin{array}{l}0.011 \\
(0.579 \\
\end{array}$ & $\begin{array}{l}170107.203 \\
(2.105) * * \\
\end{array}$ & $\begin{array}{l}0.118 \\
(0.113) \\
\end{array}$ & $\begin{array}{l}0.001 \\
(-0.078) \\
\end{array}$ & $\begin{array}{l}3547.856 \\
(0.901) \\
\end{array}$ & $\begin{array}{l}0.037 \\
(0.573) \\
\end{array}$ \\
\hline Off-farm income & $\begin{array}{l}-0.031 \\
(-0.952) \\
\end{array}$ & $\begin{array}{l}11376.958 \\
(0.222)\end{array}$ & $\begin{array}{l}-0.122 \\
(-0.217) \\
\end{array}$ & $\begin{array}{l}0.000 \\
(-0.061)\end{array}$ & $\begin{array}{l}13.498 \\
(0.023)\end{array}$ & $\begin{array}{l}0.112 \\
(-0.408) \\
\end{array}$ \\
\hline Occupation & $\begin{array}{l}-54188.239 \\
(-2.439) * * \\
\end{array}$ & $\begin{array}{l}-107546.963 \\
(-1.035)\end{array}$ & $\begin{array}{l}-1.416 \\
-1.246 \\
\end{array}$ & $\begin{array}{l}-2563.171 \\
(-0.401) \\
\end{array}$ & $\begin{array}{l}293.531 \\
(0.033) \\
\end{array}$ & $\begin{array}{l}0.175 \\
(0.391) \\
\end{array}$ \\
\hline Interest & $\begin{array}{l}-630.049 \\
(-0.409) \\
\end{array}$ & $\begin{array}{l}2035.586 \\
(0.066) \\
\end{array}$ & $\begin{array}{l}-0.316 \\
(0.936) \\
\end{array}$ & $\begin{array}{l}-403.777 \\
(-1.141) \\
\end{array}$ & $\begin{array}{l}2608.699 \\
(1.899) \\
\end{array}$ & $\begin{array}{l}-0.031 \\
(-0.455) \\
\end{array}$ \\
\hline Loan size & $\begin{array}{l}1.001 \\
(27.927) *\end{array}$ & $\begin{array}{l}193564.242 \\
(3.219) *\end{array}$ & $\begin{array}{l}1.460 \\
(2.218) * *\end{array}$ & $\begin{array}{l}0.651 \\
(12.079) *\end{array}$ & $\begin{array}{l}6169.913 \\
(2.137) * *\end{array}$ & $\begin{array}{l}0.714 \\
(4.980) *\end{array}$ \\
\hline Duration & $\begin{array}{l}-6073.701 \\
(-3.612) *\end{array}$ & $\begin{array}{l}-467481.491 \\
(-3.040) *\end{array}$ & $\begin{array}{l}-1.027 \\
(0.750) \\
\end{array}$ & $\begin{array}{l}-687.117 \\
(-1.279) \\
\end{array}$ & $\begin{array}{l}-7404.503 \\
(-1.178) \\
\end{array}$ & $\begin{array}{l}-0.192 \\
(-0.614) \\
\end{array}$ \\
\hline Installment & $\begin{array}{l}4531.177 \\
(-3.041) * *\end{array}$ & $\begin{array}{l}65453.870 \\
(2.466) * *\end{array}$ & $\begin{array}{l}0.048 \\
(0.166) \\
\end{array}$ & $\begin{array}{l}1640.631 \\
(3.593) *\end{array}$ & $\begin{array}{l}3083.241 \\
(1.392) * * *\end{array}$ & $\begin{array}{l}0.829 \\
(7.533) *\end{array}$ \\
\hline $\mathbf{R}^{2}$ & 0.982 & 0.678 & 0.707 & 0.732 & 0.461 & 0.915 \\
\hline $\mathbf{F}$ & 120.647 & 4.061 & 4.653 & 35.251 & 11.078 & 138.714 \\
\hline Prob $>$ F & 0.000 & 0.001 & 0.000 & 0.000 & 0.000 & 0.000 \\
\hline
\end{tabular}

Note: $* * *, * * *$ denotes z-test significant at $1 \%$ and 5\% 10\% levels respectively Values in parentheses represent Z-statistic

Source: Field survey, 2016

\section{Conclusion}

The study revealed a population of farmers that are in their active, productive years, mostly married, predominantly educated, experienced in farming, have a high annual income although they operate at a small scale level.It has been concluded that farmers in the area obtained loan majorly from informal sources and 
cooperatives forms the major source of agricultural loan. Age of the farmer, sex, farm size, collateral value are factors that significantly affect farmers' access to formal loan while sex, farm size, major occupation and the interest rate are those influencing the farmers' access to informal agricultural loan.

There is a high repayment rate among farmers in the study area. However, there are a number of variables which influences repayment. The factors influencing the repayment of formal agricultural loans are loan size, major occupation, marital status, number of instalments and loan duration while only loan size and number of instalments are the significant determinants of repayment of informal loan.

It is therefore recommended that conscious use of policies directed at increasing the amount of loan obtained by farmers should be promoted. Larger loan size would enhance the beneficiaries' adoption of more capital intensive technologies and improved farm management opportunities which would lead to higher productivity, reduced per unit cost and higher income. This will enhance prompt repayment of loan. Further disbursement of loan should be directed at farmers who have other sources of income. These are more likely to repay loans. This is because the tendency to divert loans is decreased since they can earn money from other profitable ventures. Government should formulate and implement policies that will enhance farmer's access to larger farm sizes. This will help them to access formal loans since land serve as collateral which is one of the criteria of formal financial institutions. Farmers should be encouraged to belong to cooperatives in order to have good access to loan. Most cooperative societies disburse loan on the basis of membership. Formal financial institutions should look into their lending policies and also find ways of encouraging farmers to obtain loans from them.

\section{References}

[1]. P. B. Imoudu and E. Onaksaponome, Bank Loan Requirement and Availability for Nigerian Small Farmers: A comparative Analysis of Experience. African Review of Money Finance and Banking, 1, 1992, 49-61.

[2]. A. J. Adegeye, and J. S. Dittoh, Essential of Agricultural Economics (Impact Publishers Nigeria, Ltd, Ibadan 1985).

[3]. M.R. Kohansal, and H. Mansoori, Factors affecting on loan repayment performance of farmers in Kharasan-Razavi province of Iran. A paper presented in a conference on International Research on Food Security. Natural Resource Management and Rura Development, University of Hamburg. http//:www.tropintag.de/264.pdf.

[4]. I. N. Nwachukwu, C. S. Alamba, and A. Oko-Isu, Determinants of institutional credit repayment performance among farmers in Afikpo North LGA of Ebonyi state, Nigeria. AAB BIOFLUX 2 (3), 2010, 211-226.

[5]. D. Awunyo-Victor, Determinants of loan repayment default among farmers in Ghana. Journal of Development, Agriculture and Economics.4(13), 2012, 339-345.

[6]. V. U. Oboh, L. Nagarajan and I. D. Ekpebu, A Marginal Analysis of Agricultural Credit Allocation by Arable Crop Farmers in Benue State, Nigeria, Current Research Journal of Social Sciences 3(2), 2011, 81-86.

[7]. J. A. Afolabi, Economic Analysis of Loan Repayment among Small-Scale Farmers in Oyo State, Nigeria, Journal of Social Science. 22(2), 2002, 115-119.

[8]. NPC (2006).National Population Commission, Population Census 2006

[9]. I. B. Adinya, N. F. Umoren, U. I. Ekpor, L. I. Eni, E. E. Umoh, and A. D Idio, Analysis of Formal and Informal Sources of Credit Facilities for Cassava Farmers in Obot-Akara Local Government Area of Akwa Ibom State, Nigeria, Advanced Journal of Business Management and Entrepreneurship.1(2), 2013, 30-41.

[10]. B. C. Asogwa, O. Abu, and G. E. Ochoche, Analysis of Peasant Farmers' Access to Agricultural Credit in Benue State, Nigeria. British Journal of Economics, Management and Trade, 4 (10), 2014, 1525-1543.

[11]. R. A. Ololade and F. I. Olagunju, Determinants of Access to Credit among Rural Farmers in Oyo State, Nigeria Global Journal of Science Frontier Research, 8(2), 2013, 16-22.

[12]. K. I. Etonihu, K. I., Rahman, S. A. and S. Usman, Determinants of access to agricultural credit among crop farmers in a farming community of Nasarawa State, Nigeria, Journal of Development and Agricultural Economics 5(5), 2013,192-196.

[13]. F. I. Olagunju, Impact of credit access on value chain activities of Agro- Processing Industries in Oyo State, Nigeria, International Journal of Agricultural Science. 3(8), 2013, 636-648.

[14]. V. U. Oboh, and S. Kushwaha.Socio-economic Determinants of Farmers' Loan Size in Benue State, Nigeria. Journal of Applied Sciences Research, 5(4), 2009, 354-358.

[15]. I. A. Ojiako and B. C. Ogbukwa, Economic analysis of loan repayment capacity of Smallholder Cooperative Farmers in Yewa North Local Government Area of Ogun State, Nigeria, African Journal of Agricultural Research. 7(13), 2012, 2051-2062

[16]. O. Adejobi, and J. T. Atobatele, An analysis of loan delinquency among small-scale farmers in south western Nigeria: Application of logit and loan performance indices, East African Agricultural and Forestry Journal.74 (3) 2008 ,

[17]. E. A. Ajah., E.O. Eyo and U.I. Ofem, Analysis of Credit Worthiness and Loan Repayment among Bank of Agriculture Beneficiaries (Poultry farmers) in Cross River State, Nigeria, International Journal of Livestock Production, 5(9), 2014, 156-164.

[18]. U. A. Akpan, E. J. Udoh and S. B. Akpan, Analysis of loan default among agricultural credit guarantee scheme (ACGS) loan beneficiaries in Akwa Ibom State, Nigeria, African Journal of Agricultural Economics and Rural Development, 2 (2), 2014, 121128.

[19]. C. A Wongnaa, D. Awunyo-Victor, Factors Affecting Loan Repayment Performance among Yam Farmers in the Sene District, Ghana. Agris on-line Papers in Economics and Informatics 5(2), 2013, 111-122. 